\title{
CONFLICT HANDLING STYLES WITHIN LOCAL SELF-GOVERNMENT MANAGERS IN THE SLOVAK REPUBLIC
}

\section{Eliska Zupova}

Pavol Jozef Safarik University in Kosice, Faculty of Public Administration, Kosice, Slovak Republic

OMESTE

JEL Category: H70, Z18

\begin{abstract}
The aim of the contribution is to present the partial nationwide research results aimed to find out the conflict handling style most used by mayors to resolve conflicts. A synthesis of the basic ideas of the theories of the mentioned authors is about the typology of five conflicting handling styles, namely avoiding, competition, adjustment, cooperation, and compromise. There are many conflicts handling styles used by individuals. It depends on the specificity of the situation, the structure and dynamics of the relationship, and, finally, the disposition characteristics of the actors involved in the conflict. The research results were processed using the primary data analysis and by using descriptive statistical methods. The research sample consisted of a core set of objects. There had been addressed all mayors of 2,753 municipalities in the Slovak Republic. Research sample were mayors of the Slovak Republic. The distribution of the sample by gender is in favor of men (67.6\%), the highest number of respondents has a university education (51.5\%). Based on the results, it was found out, that cooperation is the preferred conflict handling style by older women mayors, university graduates, in the second term of office, and in municipalities with over 1001 inhabitants.
\end{abstract}

Keywords: conflict, conflict situations, conflict handling style, mayor

\section{INTRODUCTION}

Conflicts are part of our everyday life - family, work and social. They are a natural manifestation of disagreements, exchanges of opinions, inconsistencies between the demands of individuals and groups. Conflicts disturb the balance of life, cause stress and anxiety. Conflicts, however, also have a positive impact - giving the opportunity for a new and creative approach to

Address of the author:

Eliška Župová

帮" eliska.zupova@upjs.sk problem-solving. The positive function of the conflict is, for example, in releasing negative tension, evaluating relationships among people, or increasing interest in solving problems. The basic problem, however, is not in the existence of a conflict, perhaps even in its prevention, but above all in the way of its solution (Zupova, 2015).

All interpersonal conflicts, whether occurring between employees and their superiors, family members or partners, have some common elements. One from the popular definitions of the conflict offered by Coser in the 1960s (in Wilmot \& Hocker, 2004), arguing that the conflict is a 
struggle for values and a demand for deficient status, power, and resources, in which opponents' goals are to neutralize, injure or destroy rivals.

Conflict is generally defined as a mismatch of interests or thoughts, attitudes. It is about a situation where one party perceives that its interests are opposed to the interests of another person (Wall \& Callister, 1995).

Rahim (1992) understands the conflict as an interactive process manifested by incompatibility, disagreement or mismatch within or between social entities. Interaction with others supports the existence of different values, which in some cases can cause tension and friction between the parties involved. Current definitions of conflict focus largely on interdependence to an unchangeable opposition. Conflicting parties are presented as essentially interdependent. In addition, it may be necessary for at least one person to change their perception of the situation. Conflict is often accompanied by strong emotions (especially anger) and requires "doing something". By synthesis of given knowledge, we can understand the conflict as an expression of disagreement between at least two interdependent parties perceiving incompatible goals, lack of resources, and interfere with others in achieving their goals (Wilmot \& Hocker, 2004)

In general, conflict handling style can be broken down into two poles according to (a) the degree of interest in each other or (b) the degree of interest in others (Blake \& Mouton, 1970; Rahim, 1983; Cann, Norman, Welbourne, \& Calhoun, 2008). The dimension of interest represents the significance of a given conflict handling style, which will satisfy its own priorities. The dimension of interest on others, on the contrary, represents the need to ensure that the other person resolves the conflict according to their own ideas.

Based on the mentioned dimensionality, several authors (Pruitt \& Rubin, 1986; Rahim, 1973; Thomas \& Kilman, 1974; Wilmot \& Hocker, 2004) developed conflictual style theories; strategies. A synthesis of the basic ideas of the theories of the mentioned authors is about the typology of 5 conflicting handling styles, namely:

1. Avoiding,

2. Competition,

3. Adjustment,

4. Cooperation,

5. Compromise.
Avoiding - it is a non-assertive and noncooperative conflict resolution strategy. An individual is not interested in solving a conflict and is not interested in meeting the requirements of the other party. Thus, the individual does not deal with the conflict and ignores the passive problem. This can happen in the form of a diplomatic avoided problem, postponing the problem at a more appropriate time, or simply withdrawing from a threatening situation. It's an escape strategy where both sides are losing. However, it should be remembered that this conflict resolution strategy is only a temporary solution. This strategy is appropriate to apply if it is a minor matter, there is no time to resolve the conflict or if a satisfactory solution can not be reached. Also, if we know that other people are better able to solve the problem or when we realize that potential conflict losses outweigh the potential gain.

Competition - is an assertive and non-cooperative conflict resolution strategy. An individua monitors his/her own interests at the expense of another person. An individual has a strong interest in pursuing their solution and not interested in the goals of the other party - he is highly concentrated on himself. This is so-called "a force-based conflict resolution strategy" that uses as much power as it is necessary to gain its own dominant position. It is negotiated using tactics and the position of interest and power. In this case, it is the ability to use argumentation, position, or advantageous economic situation. Contesting means "to stand up for your rights", to defend the position that is assumed (and believes in it) to be right or to simply try to win. This strategy disturbs relations because the other side will try to repress the attitude of the first party. This strategy should be applied if we decide on timing or if we introduce unpopular measures with which the other party does not agree. The advantage of implementing this strategy is the speed of conflict resolution.

Adjustment - is a non-assertive and cooperative conflict resolution strategy. It is a complete antagonism of competition and applies if the relationship of power between the parties is unbalanced. One party dictates the terms and the other party for any reason will not approach them. In the case of this strategy, an individual disregard his/her own interests, solves the conflict to satisfy the interests of another person - hence the element of self-sacrifice. Applying this strategy 
emphasizes maintaining a relationship with another person at the expense of a positive outcome. Only one side always wins the second plays. Adaptation may take the form of a nonHebrew or charity, or a form of subordination to another person, or the admission of another person's view. This strategy should be applied if you are not right when you want others to learn from their mistakes or in cases where you want to show that you are reasonable, and you can recognize the truth of another when you want to promote co-operation, harmony, or if you want to minimize losses from conflict resolution. This conflict resolution strategy is only a temporary solution to the conflict and is totally unsuitable for managers.

Cooperation - there is also an assertive and cooperative conflict resolution strategy. It is the opposite of avoiding. Collaboration involves trying to work with others to find a solution that fully satisfies their interests. The parties strive to reach their interest, and they are also interested in the position of the other party. This is an analysis of the problem to identify/highlight the essential needs of two individuals. When implementing this strategy, the understanding of the conflict is functional, both sides cooperate with one another, there is a willingness to open information exchange. Collaboration between two people can take the form of exploring disagreement, learning from each other, or trying to find a creative solution for human problems. As a result, both sides win, are satisfied and accept the solution. An advantage is a long-term effectiveness because it addresses the core of the problem (not the symptoms). The disadvantage is time-consuming, so it is not appropriate in crisis situations.

Compromise - is a slightly assertive and slightly cooperative conflict resolution strategy. The aim is to find a suitable, mutually acceptable solution that will partially satisfy both parties by giving up part of their demands. It is an "intermediate category" between competition and adaptation. In a compromise, a person gives up more than in competition, but less than in personalization. Also, in a compromise, an individual solves the problem more directly than avoiding but does not explore the problem to the depth of cooperation. The result of this strategy is to find a compromise, a common solution. Both parties are losing because they sacrificed a lot and are disappointed. (Zupova, 2015).

The strategies are used by individuals to deal with conflict situations are of course many, depending on the specificity of the situation, the structure and dynamics of the relationship, and, last but not least, the disposition characteristics of the actors involved in the conflict. From the point of view of the nature of the contribution, the aim of the research is to map the issue of conflicts and conflict handling style in the context of selected variables.

\section{RESEARCH}

\section{Aim}

The aim of contribution is to find out the conflict handling style most used by mayors to resolve conflicts.

\section{Research file}

The research file was the basic set of objects. According to the Statistical Office of the Slovak Republic, to January $31^{\text {st }}, 2018$ in the territory of the Slovak Republic were 2751 municipalities. The municipal elections took place in the Slovak Republic on November $15^{\text {th }}, 2014$. The addresses were addressed by the mayors of all 2751 municipalities in the territory of the Slovak Republic.

Respondents from the research (the research sample) were mayors of the municipalities of the Slovak Republic. The respondent was sent a questionnaire electronically due to financial and time-lag. Altogether 8,209 emails were sent to 2751 municipalities in the territory of the Slovak Republic. Each of 2751 municipalities was sent at least 1 email.

A total, 787 respondents agreed with the survey, representing $28.5 \%$ return. Each respondent filled in all the questionnaire entries. In the opening text, respondents were informed of the research intention, anonymity, and request for consent to participate in the research.

The distribution of the sample by gender is in favor of men $(67.6 \%)$. Only a third $(32.4 \%)$ of all mayors are female mayors. The highest number of respondents has a university education (51.5\%), followed by those who have completed secondary education (42.4\%). Respondents were divided into nine groups based on their age. The mean 
age is 49.5 years (standard deviation of 8.84 ) with a median age of 51 years. The youngest respondent reached 26 years and the oldest 79 years. Of the total number of municipalities involved in research ( $\mathrm{n} 787), 318$ are in the category of up to 500 inhabitants (40.4\%) and in the category of up to 1000 inhabitants, there are 548 municipalities (69.7). Most respondents/mayors have experience with performing this feature. The mayor of the municipality has more than 3 terms in office of 334 respondents $(42.4 \%)$. In the second term in office, there are 206 mayors (30.0\%).

\section{Methods and Methodology}

The research was carried out using a set of methodologies, which included the following parts:

1. basic demographic issues (gender, age, education, the term in office, size of municipality)

2. The questionnaire was designed to identify an individual's tendency to resolve conflicts in challenging situations, one of the conflict resolution styles. The questionnaire contains 29 statements judged on the 7 - point Liker scale $(1$ - strongly disagree to 7 - strongly agree). To identify a preferred conflict handling style, the questionnaire includes 6 items for avoidance, 6 adjustment items, 5 competition items, 5 cooperation items, and 7 compromise items. The reliability of the individual factors calculated by Cronbach's alpha is: avoided $(\alpha=0.69)$, compromise $(\alpha=$ $0.82)$, cooperation $(\alpha=0.87)$, dominance $(\alpha=$ $0.81)$, adjustment $(\alpha=0.69)$. The questionnaire reliability is $\mathrm{a}=0.86$ (Cai, Fink, 2001).

\section{Statistical analysis}

The results of the research were processed using statistical software SPSS 21. Basic analysis of the obtained data was realized using methods of descriptive statistics

\section{Conflict handling styles used by mayors}

Each conflict is situational and content-specific. The mayor must have the skills and abilities to help him identify the problem, assess the situation, and apply an appropriate conflict handling style in conflicting situations. The best way to resolve the conflict is to cooperate with people to understand the problem properly, to make an acceptable decision for the parties involved. The mayor 's aim is to be a joint solution to the problem that meets the expectations of all parties - the mayor, the people, the staff of the office, the deputies, the business entities and others.

According to the results presented in graph 1, the preferred style of conflict resolution among municipal mayors is a cooperation style ( $\mathrm{n} 737$, $93.6 \%$ ), and the least used style ( $215 ; 27.3 \%$ ) is the dominant style (competition). The results are in line with the theoretical knowledge of conflict management. The most appropriate conflict resolution style is cooperation, as it involves trying to work with others to find a solution that will fully satisfy the interests of both sides.

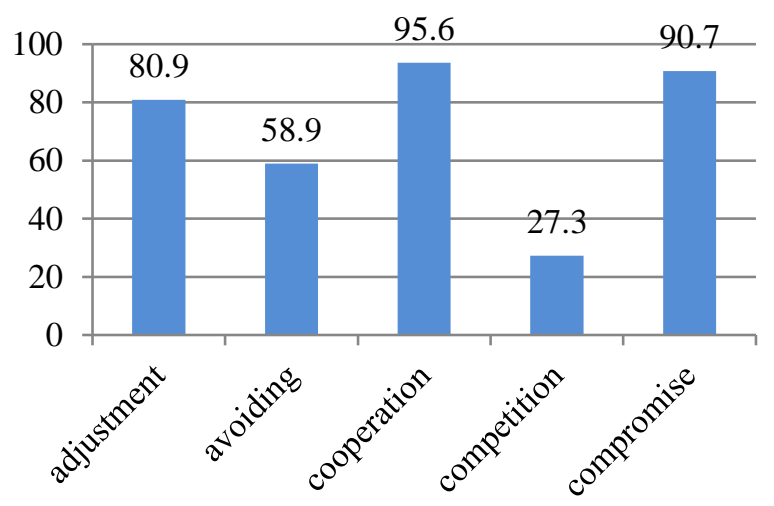

Graph 1 Conflict handling style (\% frequency)

Mayors who prefer cooperation seek to achieve their interest and are also interested in the position of the other party. This is an analysis of the problem to identify and highlight the substantial needs of the two parties. When applying this style, the understanding of the conflict is functional, the mayor cooperates with each other, there is a willingness to exchange information openly. This conflict handling style is the best and brings satisfaction to the mayor as well as the other side.

The dominant conflict handling style (competition) is based on the position of the mayor of the municipality. The Mayor has a keen interest in achieving his own goals. This style should be applied, for example, unpopular measures, or if the mayor is quick to resolve the conflict - but such a solution is only appropriate for the mayor. In the long run, the relationship between the parties and the loss of mutual trust are distorted, which the mayor cannot afford because it would affect his credibility with the environment. Mayors (n 215; 
$27.3 \%$ ) use the dominant conflict handling style at least.

In the case of adjusting style, the mayor disregards his or her own interests. Applying this style emphasizes maintaining a relationship with another person at the expense of a positive result. This conflict handling style is only a temporary solution to the conflict and is totally inappropriate for all managers, including the mayor of the municipality. Mayors prefer this style (n 637; $80.9 \%$ ). A self-confessing element acts on them to satisfy the interests of the other.

Mayors favoring the compromise handling style ( $\mathrm{n}$ $714,89.7 \%$ ) solve the problem directly, but it does not study it in depth. Its aim is to find a suitable, mutually acceptable solution that will partially satisfy both the party and the other side by giving up some of its demands - resulting in a loss for both parties and for the mayor.

Mayors with an avoiding preferred style of conflict resolution ( $\mathrm{n} 464 ; 58.9 \%$ ) are not interested in resolving conflict and are not interested in meeting the requirements of the other party. Thus, the mayors do not deal with the conflict and ignore the passive problem.

Table 1 Conflict handling style according to age

\begin{tabular}{|l|c|c|c|c|c|c|}
\hline \multirow{2}{*}{$\begin{array}{l}\text { age } \\
\text { conflict } \\
\text { handling } \\
\text { style }\end{array}$} & \multicolumn{5}{|c|}{$\begin{array}{c}\mathbf{5} \text { number } \\
\text { years }\end{array}$} & \multicolumn{2}{|c|}{$\begin{array}{c}\mathbf{4 7 - 5 4} \mathbf{y} . \\
\mathbf{n}=\mathbf{2 5 9}\end{array}$} & \multicolumn{2}{c|}{$\begin{array}{c}\mathbf{2 5 5} \\
\text { years } \\
\mathbf{n = 2 5 8}\end{array}$} \\
\cline { 2 - 7 } & $\mathbf{n}$ & $\%$ & $\mathbf{n}$ & $\%$ & $\mathbf{n}$ & $\%$ \\
\hline adjust & 224 & 83.0 & 202 & 78.0 & 211 & 81.8 \\
\hline avoiding & 163 & 60.4 & 144 & 55.6 & 157 & 60.9 \\
\hline cooperation & 249 & 92.2 & 244 & 94.2 & 244 & 94.6 \\
\hline competition & 76 & 28.1 & 75 & 29.0 & 64 & 24.8 \\
\hline compromise & 245 & 90.7 & 238 & 91.9 & 231 & 89.5 \\
\hline
\end{tabular}

Table 2 Conflict handling style according to gender

\begin{tabular}{|c|c|c|c|c|}
\hline \multirow{3}{*}{$\begin{array}{l}\text { conflict } \\
\text { handling } \\
\text { style }\end{array}$} & \multicolumn{4}{|c|}{ number } \\
\hline & \multicolumn{2}{|c|}{$\begin{array}{c}\operatorname{man} \\
\mathrm{n}=532\end{array}$} & \multicolumn{2}{|c|}{$\begin{array}{c}\text { women } \\
n=255\end{array}$} \\
\hline & $\mathbf{n}$ & $\%$ & $\mathrm{n}$ & $\%$ \\
\hline adjusting & 423 & 79.5 & 214 & 83.9 \\
\hline avoiding & 288 & 54.1 & 176 & 69.0 \\
\hline cooperation & 496 & 93.2 & 241 & 94.5 \\
\hline competition & 154 & 28.9 & 61 & 23.9 \\
\hline compromise & 480 & 90.2 & 234 & 91.8 \\
\hline
\end{tabular}

Table 3 Conflict handling style according to education

\begin{tabular}{|l|c|c|c|c|}
\hline \multirow{2}{*}{ education } & \multicolumn{4}{|c|}{ number } \\
\cline { 2 - 5 } $\begin{array}{l}\text { conflict } \\
\text { handling } \\
\text { style }\end{array}$ & $\begin{array}{c}\text { secondary } \\
\text { school } \\
\mathbf{n}=\mathbf{3 8 2}\end{array}$ & \multicolumn{2}{c|}{$\begin{array}{c}\text { university } \\
\mathbf{n}=\mathbf{4 0 5}\end{array}$} \\
\cline { 2 - 5 } adjusting & $\mathbf{n}$ & $\%$ & $\mathbf{n}$ & $\%$ \\
\hline avoiding & 310 & 81.2 & 327 & 80.7 \\
\hline cooperation & 234 & 61.6 & 230 & 56.8 \\
\hline competition & 352 & 91.1 & 385 & 95.1 \\
\hline compromise & 34 & 22.0 & 131 & 32.3 \\
\hline
\end{tabular}

We were interested in preferred conflict resolution styles according to socio-demographic characteristics (age, gender, education, the term of office and size of the municipality) of mayors. Differences are presented in Tables 1 to 5 .

Table 4 Conflict handling style according to term in office

\begin{tabular}{|c|c|c|c|c|c|c|}
\hline \multirow[b]{3}{*}{ conflict handling style } & \multicolumn{6}{|c|}{ number } \\
\hline & \multicolumn{2}{|c|}{$\begin{array}{c}\text { first } \\
n=217\end{array}$} & \multicolumn{2}{|c|}{$\begin{array}{c}\text { second } \\
n=236\end{array}$} & \multicolumn{2}{|c|}{$\begin{array}{c}\text { third } \\
n=334\end{array}$} \\
\hline & $\mathbf{n}$ & $\%$ & $\mathbf{n}$ & $\%$ & $\mathbf{n}$ & $\%$ \\
\hline adjusting & 179 & 82.5 & 175 & 74.2 & 283 & 84.7 \\
\hline avoiding & 143 & 65.9 & 120 & 50.8 & 201 & 60. \\
\hline cooperation & 208 & 89.8 & 212 & 95.9 & 317 & 94.9 \\
\hline competiti & 62 & 24.6 & 58 & 28.6 & 95 & 28.4 \\
\hline & 19 & & & & & 91 \\
\hline
\end{tabular}

Table 5 Conflict handling style according to the size of the municipality

\begin{tabular}{|l|c|c|c|c|c|c|}
\hline \multirow{2}{*}{$\begin{array}{r}\text { size of } \\
\text { municipality }\end{array}$} & \multicolumn{6}{|c|}{ number } \\
\cline { 2 - 7 } $\begin{array}{l}\text { conflict } \\
\text { handling } \\
\text { style }\end{array}$ & $\begin{array}{c}\mathbf{5} \text { 500 } \\
\mathbf{n}=\mathbf{3 2 4}\end{array}$ & $\begin{array}{c}\mathbf{5 0 1 - 1 0 0 0} \\
\text { inhabitants } \\
\mathbf{n}=\mathbf{2 2 4}\end{array}$ & $\begin{array}{c}>1000 \\
\text { inhabitants } \\
\mathbf{n}=\mathbf{2 3 9}\end{array}$ \\
\cline { 2 - 7 } adjusting & 267 & 82.4 & 177 & 79.0 & 193 & 80.8 \\
\hline avoiding & 193 & 59.6 & 138 & 61.6 & 133 & 55.6 \\
\hline cooperation & 305 & 94.1 & 205 & 91.5 & 227 & 95.0 \\
\hline competition & 76 & 23.5 & 60 & 33.1 & 79 & 26.8 \\
\hline compromise & 293 & 90.4 & 203 & 90.6 & 218 & 91.2 \\
\hline
\end{tabular}

According to the age differences in table 1, cooperation is the most appropriate conflict handling style for mayors in the 55+ category (n 244; $94.6 \%$ ). Older mayors, because of their life and work experience, have the problem solved constructively. Mayors under 46 prefer to adapt to 
conflict situations (n 224, 83.0\%). Such a solution to the conflict is only temporary, for the mayor as a manager inappropriate.

The results were also considered in terms of gender differences. From table 2, in women, worries dominate conflict resolution - competition (n 241; 94.5\%) or compromise (n 234; 91.8\%). They use a cooperation style to maintain interpersonal relationships and prefer to avoid direct negative confrontation. Men use a dominant style (competition) to resolve the conflict ( $\mathrm{n} \mathrm{154}$; $28.9 \%$ ). Men are known to tend to give their strength and dominance. According to Mikulastik (2008), men feel uncomfortable in working with women. Thomas and Kilmann (1988) report the same results in their research. Men managers prefer dominant access to employees, while employee management prefers authoritarian style, which results in their conflict handling style. Men are oriented towards achieving the goals at the expense of positive interpersonal relationships at the workplace.

From the point of view of education (table 3), cooperation ( $\mathrm{n} 385 ; 95.1 \%$ ) predominates as a preferred conflict resolution style and a compromise (n 373; 92.1\%) for universityeducated mayors. The results are in line with Saeed's research (2013), which states that more educated individuals use a collaborative style of conflict resolution.

The differences in the term of office of mayors are presented in table 4 . The mayors in the first term use avoiding as a preferred conflict resolution style (n 143; 65.9\%). We expected such a finding. Mayors prefer to passively ignore the problem because they are the mayor for the first time and need to maintain good relationships - otherwise, their success in the second election does not have to be repeated. The mayor in the second term of office dominates cooperation (n 212, 95.9\%). It is also a group of mayors dominated by the dominant

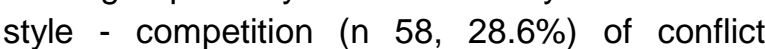
resolution. We believe that this is caused by the fact that the mayor is in the position of being certain and is aware of the social environment of the municipality. It is also possible to claim dominance from the position of power.

In his research, Copley (2008) presented the results of his preferred conflict handling style to managerial positions with regard to the size of the organization. According to his findings, managers of small organizations prefer cooperation and compromise, and managers of large organizations prefer competition. If the number of inhabitants in which the mayor is acting perceives the size of the organization, the results of our study are different. Mayors in small municipality prefer adjusting as the preferred conflict resolution style (n 267; $82.4 \%$ ). We think this is because the mayor is known in the municipality, trying to maintain good interpersonal relationships in a smaller community.

Based on the results, we note that co-operation is the preferred conflict handling style by older women mayors, university graduates, in the second term of office, and in municipalities with over 1001 inhabitants.

\section{CONCLUSIONS}

The contribution focused on conflict issues. It tried to clarify what types of conflicts the respondents most often encounter and with whom they enter the conflicts. As it turned out, most of the conflicts that covered the field of affairs were solved. As an effective conflict handling style, respondents chose, in particular, a compromise. It is a constructive way of resolving a conflict.

We consider it important to address the problem of conflict handling style within the mayors. Each conflict is situational and content-specific. The mayors should have the skills and abilities to help him/her identify the problem in conflict situations, assess the situation and apply the appropriate style of conflict resolution, not only in personal but also in working life.

\section{WORKS CITED}

Blake, R. R. \& Mouton, J. S. (1970). The fifth achievement. Journal of Applied Behavioral Science, (6), 413-426. 
Cai, D., Wilson, S., \& Drake, L. (2001). Culture in the context of intercultural negotiation: Individualismcollectivism and paths to integrative agreements. Human Communication Research, 69(1), 6787.

Cann, A., Norman, A., Welbourne, J., \& Calhoun, L. (2008). Attachment styles, conflict styles, and humor styles: Interrelationships and associations with relationship satisfaction. European Journal of Personality, (22), 131-146.

Copley, R. (2008). Conflict management styles: a predictor of likability and perceived effectiveness among subordinates. Master Thesis. Indiana University.

Kilmann, H., \& Thomas, W. (1977). Developing a forced-choice measure of conflict-handling behavior: The "MODE" instrument. Educational and Psychological Measurement, 37(2).

Mikulastik, M. (2008). Socialni kompetence. Bratislavska vysoka skola prava. Bratislava.

Pruitt, D., \& Rubin, J. (1986). Social Conflict. New York: McGraw-Hill.

Rahim, M. A. (1983). A measure of styles of handling interpersonal conflict. Academy of Management Journal, 26(2), 368-376.

Rahim, M. A. (1992). Managing Conflict in Organizations. New York: Praeger.

Rahim, M. A. (2011). Managing conflict in organizations. Transaction Publishers.

Rahim, M. A., \& Magner, N. R. (1994). Convergent and discriminant validity of the Rahim Organizational Conflict Inventory-II, Psychological Reports, (74), 35-38.

Rahim, M. A., \& Magner, N. R. 1995. Confirmatory factor analysis of the styles of handling interpersonal conflict: First-order factor model and its invariance across groups. Journal of Applied Psychology, (80), 122-132.

Saeed, R., Lodhi, R. N., Ahmed, S., Munir, H. M., Dustgeer, F., Sami, A., Mahmood, Z., \& Ahmad, M. (2013). Effect of Conflicts in Organizations and its Resolution in Pakistan. World Applied Sciences Journal, 26, 393-398.

Thomas, K. L., \& Kilman, R. H. (1974). The Thomas - Kilman Conflict Mode Instrument. Tuxedo, NY: Xicom.

Wall, J. A., \& Callister, R. R. (1995). Conflict and its management. Journal of Management, 21(3), 515558.

Wilmot, W. W., \& Hocker, J. L. (2004). Interpersonalny konflikt. Bratislava: IKAR.

Zupova, E. (2015). Konflikty na pracovisku a strategie ich riesenia. In Gabriela Kravcakova a kol. (Eds.), Organizacne spravanie vysokoskolska ucebnica - druhe prepracovane a doplnene vydanie (p. 345-359). Kosice, Univerzita Pavla Jozefa Safarika v Kosiciach.

Received for publication: 16.02 .2018

Revision received: $\quad 28.08 .2018$

Accepted for publication: 27.12 .2018

\section{How to cite this article?}

Style - APA Sixth Edition:

Zupova, E. (2019, January 15). Conflict handling styles within local self-government managers in the Slovak Republic. (Z. Čekerevac, Ed.) MEST Journal, 7(1), 156-163. doi:10.12709/mest.07.07.01.18 
Style - Chicago Sixteenth Edition:

Zupova, Eliska. 2019. "Conflict handling styles within local self-government managers in the Slovak Republic." Edited by Zoran Čekerevac. MEST Journal (MESTE) 7 (1): 156-163. doi:10.12709/mest.07.07.01.18.

Style - GOST Name Sort:

Zupova Eliska Conflict handling styles within local self-government managers in the Slovak Republic [Journal] // MEST Journal / ed. Čekerevac Zoran. - Belgrade - Toronto : MESTE, January 15, 2019. 1 : Vol. 7. - pp. 156-163. doi:10.12709/mest.07.07.01.18.

Style - Harvard Anglia:

Zupova, E., 2019. Conflict handling styles within local self-government managers in the Slovak Republic. MEST Journal, 15 January, 7(1), pp. 156-163.

Style - ISO 690 Numerical Reference:

Conflict handling styles within local self-government managers in the Slovak Republic. Zupova, Eliska. [ed.] Zoran Čekerevac. 1, Belgrade - Toronto : MESTE, January 15, 2019, MEST Journal, Vol. 7, pp. 156-163. 